\title{
Welcome to Porto Alegre!
}

Brazil is a country of continental proportions, with enormous geological wealth and potential for new discoveries based on innovative research techniques. There are demands for the increase of knowledge on country's geology. The $48^{\text {th }}$ Brazilian Congress of Geology ( $48^{\text {th }} \mathrm{BCG}$ ) will play an important role in bringing this knowledge together from academia, industry, professionals and society through courses, talks and discussions.

Since 1947, the Brazilian Congress of Geology has been held in the main Brazilian cities. The last one, held in Rio Grande do Sul in 1974 (42 years ago), is considered a milestone in participation and publications for the time, with the annals printed in 7 volumes. This state has a strong tradition in teaching Geosciences, having 4 undergraduate schools in Geology and several graduate courses involving a significant number of faculty and students.

The $48^{\text {th }}$ BCG, whose slogan is “The Geotechnologies and the $21^{\text {st }}$ Century", will be held from October $9^{\text {th }}$ to $13^{\text {th }}$, 2016, at the FIERGS events center in Porto Alegre, Rio Grande do Sul. The congress intends to show new technologies to geoscientists distributed in 35 thematic sessions, as well as to offer keynote speakers given by acclaimed researchers engaged in key studies on issues currently debated within Brazilian society.

High-profile technical excursions will be offered, including visits to areas with geological significance, to give the participants the opportunity to exchange knowledge. After the congress, excursions to the Parnaiba and Paraná basins, Andean region of Chile and Argentina, Sul-rio-grandense Shield, canyons region and others areas are planned.

In addition, the program of the $48^{\text {th }}$ BCG has been designed to debate key Geology themes in Conferences, Round Tables, Panels and Mini Courses. The number of visitors to BCG has been increasing and, given the concentration of Geology professionals and students in the southern and southeastern regions, it is expected that in 2016 the BCG will open its doors to approximately 4,000 participants.

Simultaneously with the event, EXPOGEO 2016 will showcase technical exhibits of services and products offered by public and private companies, research institutions and non-governmental organizations. We reserved 4,500 $\mathrm{m}^{2}$ in FIERGS for this event.

For more information go to www.48cbg.com.br, and find details of the congress. The abstracts can be submitted via website until 24 ${ }^{\text {th }}$ April 2016.

We are waiting for you in Porto Alegre!

Gerson Fauth

Instituto Tecnológico de Micropaleontologiaitt Fossil, Universidade do Vale do Rio dos Sinos (UNISINOS), Cidade de São Leopoldo (RS), Brasil

Mauro Daniel Rodrigues Bruno

Instituto Tecnológico de Micropaleontologia itt Fossil, Universidade do Vale do Rio dos Sinos (UNISINOS), Cidade de Sáo Leopoldo (RS), Brasil 